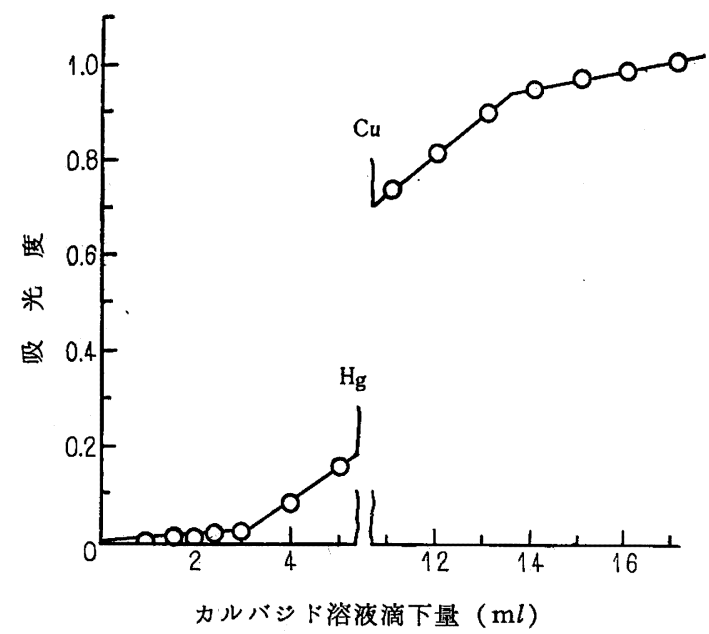

水銀濃度: $0.86 \mathrm{mg} / 50 \mathrm{ml}$, 銅浱度: $1.0 \mathrm{mg} / 50 \mathrm{ml}$

図 3 水銀, 銅同時滴定曲線

結果が図 3 である。使用波長は銅錯塩の極大吸収付近の $655 \mathrm{~m} \mu$ を使用した。水銀の滴定が終ると銅錯塩の青色発現で吸光度は急
に増大していき，第 2 の直線部分の交点が銅の当量点である。こ の場合カルバジド自身の吸収にないが銅錯塩生成反応は完結しな いから，この当量点を過ぎても呈色度は時間経過ととむにやや増 加するから吸光度は增していき図のように傾斜する。同時滴定結 果を表 10 に示すが当量関係は $0.003 \mathrm{~mol} / l$ カルバジド溶液 $1 \mathrm{ml}$ 注銅 $0.0950 \mathrm{mg}$ に相当する。なお，銅含量が $1.5 \mathrm{mg}$ 以上にな ると $2 \mathrm{~N}$ 酢酸酸性では銅錯塩は一部沈殿し, 始めて液が濁ってく るので当量点前後の吸光度値が乱れてはっきりした 2 直線の交点 として当量点を求めることができない。しかし，酸濃度を増せば 銅錯塩の溶解度が大きくなるから定量限度を増すことができる。 たとえば, 初めの滴定時の酸浱度を約 $4 \mathrm{~N}$ にしたときは銅含量 $1.7 \mathrm{mg}$ でも定量可能である。しかし，これ以上の銅含量になれ ば液量 $50 \mathrm{ml}$, 波長 $655 \mathrm{~m} \mu$ では銅錯塩の呈色度も濃くなって吸 光度值む 2 亿近くなり, 当量点前後の 2 直線部分の傾斜の差も少 なくなってはっきりした交点が得られにくくなる。

終りに本実験に協力された学生池上 武君に感謝する。

(1960 年 10 月, 日本化学会関東支部, 近裁支部, 高分子学会 北陸支部合同高田大会請演）

\title{
ベンジルドデシルアミンによるゥランの抽出挙動
}

(昭和 35 年 10 月 21 日受理)

松尾茂樹†

アミン類は選択性の面で他の浴媒とくらべてすぐれているため, ウランの抽出に広く使用されている。とのうちべンジル基をる つ第二アミン類は高い抽出力学も着目されているが，ての種のアミン類による抽出の基礎が明らかでない。したがってべンジル ドデシルァミンを使ってゥランの抽出挙動および抽出機榊を調べた。硫酸ナトリウム $0.1 \sim 1.0 \mathrm{~mol} / l$, 酸性度 $0.1 \sim 1.0 \mathrm{~N}$ の広

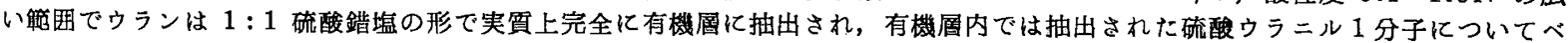
ンシルドデシルア ミンの 4 個が配位する。

\section{1 緒产}

アミン類による抽出分離法が，トリブチルリン酸その他の試薬 を用いる場合にくらべて選択性も良く，有利な点も多いので最近 さかんに利用されている。これに関しては米国その他で多数の研 究がなされており1，その絬果ベンジル基をむつ第二アミン類が ウランの抽出に特殊な役割を果していることが知られている2。 しかしこの種のアミン類の抽出の基礎が明らかでないので, 著者 はベンシルドデシルアミンを使用してウランの抽出挙動および抽 出機構を検討しているが，その一環として硫酸溶液における抽出 結果から二，三考察したことについて報告する。本実駗では溶剤 としてベンゼンを一貫して使用した。

\section{2 硫酸-硫酸ナトリゥム系におけるウランの抽出}

\section{1 酸性度}

硫酸ウラニルの溶液に硫酸を加えて, 酸性度を変化して抽出し

†東北大学理学部化学教等, 仙台河片平丁

1) D. J. Crouse, K. B. Brown, A. E. C. Rep. ORNL-1959 (1955); K. B. Brown, C. F. Coleman, J. G. Moore, ibid. AECD -4145 (1955); K. B. Brown, C. F. Coleman, D. J. Crouse, A. D. Ryon, ibid. ORLN-2268 (1957) な
たときの結果を図 1 に上げた。硫酸イオンの全浱度を $1.5 \mathrm{~N}$ に， またベンジルドデシルアミンの濃度は $0.1 \mathrm{~mol} / l$ に一定にたも った。0.01〜0.5 の酸性度範囲では抽出比は 600 以上であり変 化しないが，1N にもなると抽出比は 400 近くとなり減少した。

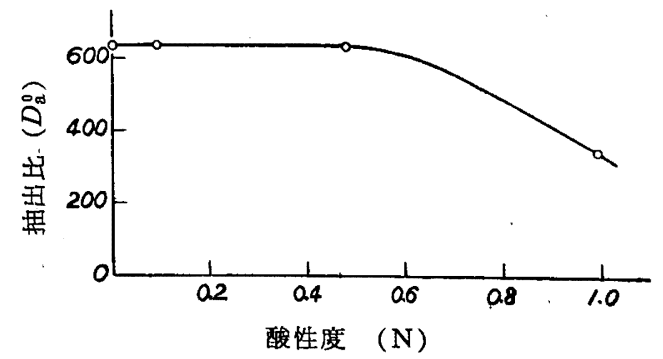

U: $4.98 \times 10^{-4} \mathrm{~mol} / l$, アミン: $0.1 \mathrm{~mol}, \Sigma S_{4}{ }^{2-}: 1.5 \mathrm{~N}$ 図 1 ウランの抽出に対する酸性度の影響

\section{2 硫酸イオンの濃度}

つぎ酸性度を一定にたもち硫酸ナトリウムの浱度を種々変化 させて，硫酸イオンのウランの抽出におよぼす影響をみたのが図

2) D. J. Crouse, K. B. Brown, W. D. Arnold, J. G. Moore, R. S. Lowrie, ibid. ORNL-2099 (1958). 
2 である。曲線 I はベンジルドデシルアミンを, 曲線II はトリノ ニルアミンを使った場合である。アミンの豲度は $0.1 \mathrm{~mol} / l$, 酸性度は $0.1 \mathrm{~N}$ にたもち, 水相および有機相の容積比はつねに等 しくした。

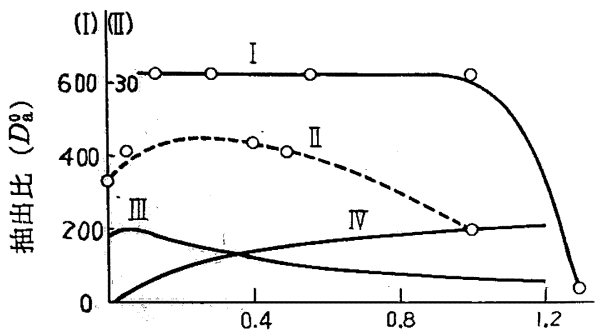

硫酸ナトリウムの溇度 $(\mathrm{mol} / l)$

$\mathrm{U}: 4.98 \times 10^{-4} \mathrm{~mol} / l$, アミン: $0.1 \mathrm{~mol} / l$, $\mathrm{H}_{2} \mathrm{SO}_{4}: 0.10 \mathrm{~N}$

図 2 ウランの抽出に対する硫酸イオン浱度の影變

ベンジルドデシルアミンを使用したときは硫酸ナトリウムの $0.1 \sim 1.0 \mathrm{~mol} / l$ の広い範囲で抽出比は 600 以上であり，一定で あった。 $1 \mathrm{~mol} / l$ をこえ $1.3 \mathrm{~mol} / l$ にむなると抽出比は減少す る。トリノニルアミンの場合は抽出比が小さいがベンジルドデシ ルアミン゙の場合と同㥞の挙動を示す。

\section{3 ウラニルーアミン会合体の組成および抽出機構}

上に述べたようにウランの抽出比は硫酸イオンの濃度によって 変化する。すなわち硫酸ウラニル鍇塩の組成および存在量に支配 される。したがって最適抽出条件や抽出機構を調べるためには， 溶液の中に存在する各種の鍇塩の組成および生成定数を知ること が望ましい。それで, 著者は分光光度法によってこれを求め, 第 1 段および第 2 段の生成定数としてそれぞれ $k_{1}=65 \pm 2, k=3 \pm$ 0.4 を得た $^{3}$ 。ただしイオン強度は 1.00 , 温度は $25^{\circ} \pm 0.1^{\circ} \mathrm{C}$ とした。1:3 の錯塩の存在はほとんど認めることができなかっ た。

一般に無機䤮塩の分子内結合はあまり強くないのでイオン強度 その他の条件によって敏感に影響を受ける。したがって DebyeHückel の補正式（1）からイオン強度を０にしたときの熱力学 的生成定数 $k_{0 n}$ を求めると, 第 1 段および第 2 段の生成定数とし てそれぞれ $k_{01}=1100, k_{02}=3$ となった。

$$
\log k_{0 n}=\log k_{n}-0.509 \Delta\left(Z_{i}^{2}\right) \frac{\sqrt{\mu}}{1+B \sqrt{\mu}}-C \mu
$$

ここで $Z_{i}$ はイオンの荷電, $\mu$ はイオン強度をあらわす。 $B$ は 2.3 とした。これは溶液中のイオン間の最近接距離 $a$ を $7 \AA$ とし たときの值である。2-2 電解質に対してはもっとも妥当な值とさ れている。またCは 0.05 としだ)。

このように活量係数の変化が生成定数の值に大きな影響をおよ ぼすので（1）にしたがって実際の抽出条件における生成定数を 求めた。これを表 1 第 4,5 欄に上げた。

3) 松尾, 日化 81, 833 (1960).

4) K. A. Kraus, F. Nelson, J. Am. Chem. Soc. 72, 3901 (1950). お 上び, R. A. Robinson, H. S. Harned, Chem. Rews. 28, 419 (1941) からとった. さいわい $a$ が 6 7.5 凡変化してb $B$ の偹は $2.2 \sim 2.3$ で あり $k_{n}$ と $\mu$ の相対的変化に大きな影然を与えない，また $C$ の值は $0.05 \sim$ 0.10 で絬果には $1 \%$ 以内の差しかもたらさない.

\begin{tabular}{|c|c|c|c|c|c|c|}
\hline \multirow[b]{2}{*}{$\begin{array}{c}\mathrm{H}_{2} \mathrm{SO}_{4} \\
(\mathrm{~mol} / \mathrm{l})\end{array}$} & \multicolumn{3}{|c|}{ 表 } & & \multirow[b]{2}{*}{$\begin{array}{c}\mathrm{UO}_{2}\left(\mathrm{SO}_{4}\right)_{2}{ }^{2-} \\
(\%)\end{array}$} \\
\hline & $\begin{array}{l}\mathrm{Na}_{2} \mathrm{SO}_{4} \\
(\mathrm{~mol} / l)\end{array}$ & $\begin{array}{c}\mathrm{SO}_{4}^{2-} \\
(\mathrm{mol} / l)\end{array}$ & $k_{1}$ & $k_{2}$ & $\begin{array}{c}\mathrm{UO}_{2} \mathrm{SO}_{4} \\
(\%)\end{array}$ & \\
\hline 0.04 & 0.10 & 0.094 & 90.8 & 3 & 71.5 & 20.2 \\
\hline " & 0.30 & 0.286 & 64.6 & " & 52.3 & 44.9 \\
\hline " & 0.50 & 0.478 & 57.3 & " & 40.5 & 58.0 \\
\hline " & 1.00 & 0.967 & 54.0 & " & 25.5 & 74.0 \\
\hline " & 1.30 & 1.27 & 55.3 & " & 20.8 & 78.9 \\
\hline
\end{tabular}

また硫酸一硫酸ナトリウム系の遊踓の硫酸イオンの浱度はBaes の測定値5)から計算して表 1 第 3 欗に上げた。質量作用の法則加 ら導いた (2) により*1 各銷体の存在量を求めると第 6,7 㦨の ようになる。これから各錯体の存在比を図示すると図 3 のように なる。

$$
\left.\begin{array}{l}
{\left[\mathrm{UO}_{2} \mathrm{SO}_{4}\right]=\frac{K_{1}\left[\mathrm{SO}_{4}\right]}{1+K_{1}\left[\mathrm{SO}_{4}\right]+K_{2}\left[\mathrm{SO}_{4}\right]^{2}}} \\
{\left[\mathrm{UO}_{2}\left(\mathrm{SO}_{4}\right)_{2}{ }^{2-}\right]=\frac{K_{2}\left[\mathrm{SO}_{4}\right]^{2}}{1+K_{1}\left[\mathrm{SO}_{4}\right]+K_{2}\left[\mathrm{SO}_{4}\right]^{2}}}
\end{array}\right\}
$$

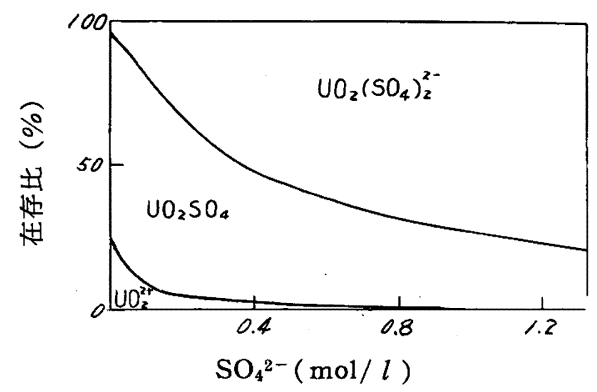

図 3 硫酸ウラニル錯塩の存在比

図 1の曲線 II， Nははそれぞれ 1:1 および 1:2 鍇体の存在量 をあらわした曲線である（縦䡅のスケールは任意にとった）。硫 酸イオンの浱度が増すにしたがって $1: 1$ 錯体の生成量はいった ん極大值を経て 減少する傾问にあるが， $1: 2$ 鍇体の場合は硫酸 イオンの源度とともに漸次増大する。したがってもしウランが $1: 2$ 錯塩の形で有機層に抽出されるならば，少なくとも実験範 囲の硫酸イオンの浱度 $(1.3 \mathrm{~mol} / l)$ までは硫酸イオンの浱度の 増加とともに抽出比は大となるべきである。しかし硫酸イオンの 濃度の高いところでは抽出比は逆に滅少しており, $1: 1$ 錯体の 存在量の低下に対応している。トリノニルアミンの抽出曲線 $\mathbf{1}$ おいてこの傾向はいちじるしい。これから見ればウランは $1: 1$ 硫酸鍇塩の形で抽出されるむのと考えられる。抽出比はアるン会 合体の結合の強さに刘応するものであると一義的に解釈すれば, 抽出力の 小さなトリノニルアミン（曲線 II）の場合は抽出比は $1: 1$ 錯体の生成量（曲線吕）の減少に良く対応するが, 抽出力 の大きいベンジルドデシルアミン（曲線 I）では $1: 1$ 錯体の生 成のわずかな変動に左右されない。しかし $1: 1$ 錯体の存在量が かなり減少すると抽出比の減少が見られる（図 1 )。

したがって $n \mathrm{~mol}$ のアミン酸性硫酸塩 ${ }^{6}$ が $1 \mathrm{~mol}$ の硫酸ウラ ニルと反応してアミン会合体を生ずるとすれば抽出のさいの平衡

5) C. F. Baes, J. Am. Chem. Soc. 79, 5611 (1957).

*1 とてて $K_{n}$ は $K_{n}=\prod_{i=1}^{n} k_{i}$ をあらわす.

6) K. A. Allen, J. Phys. Chem. 60, 239, 943 (1956) の实験式加計算

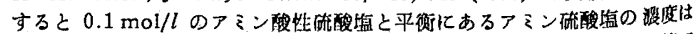
$10^{-5} \mathrm{~mol} / \mathrm{l}$ 程度であり低視しても䡖し支えない. Allen は第二わよび第三 アミンについて同様の結果をえているのでベンシルドデシルアミンに秛の式 を適用しても大るな俱りを来さないと思う。 
式は（3）であらわされる。

$$
\begin{aligned}
& n\left\{\left(\mathrm{RR}^{\prime} \mathrm{NH}_{2}\right) \mathrm{HSO}_{4}\right\}_{\text {org. }}+\left\{\mathrm{UO}_{2} \mathrm{SO}_{4}\right\}_{\text {aq. }} \rightleftarrows \\
& \quad\left\{\left[\left(\mathrm{RR}^{\prime} \mathrm{NH}_{2}\right)_{2} \mathrm{SO}_{4}\right]_{n / 2} \mathrm{UO}_{2} \mathrm{SO}_{4}\right\}_{\text {org. }}+n / 2\left\{\mathrm{H}_{2} \mathrm{SO}_{4}\right\}_{\text {aq }} .
\end{aligned}
$$

たたしアミン会合体はアミンの酸性硫酸塩を含まないと仅定し た。ウランが高濃度の硫酸溶液中でも酸性硫酸笽をつくらないこ とは一般に知られている7。

つぎウランにアミンが何個配位しているかを調べるために， ベンジルドデシルアミンの゙浱度を $0.1 \mathrm{~mol} / l$ に, 酸性度を $0.1 \mathrm{~N}$ に一定にしておき, ウランの浱度を漸次增加させたときの両相に お汀る平衡浱度を調べた。この結果を図 4 に上げた。これから ウランの最大負荷量を求めると Amine $/ \mathrm{U}=4.5$ となる。配位数 の考充からウランに配位するアミンの数は 4 ないし 6 と期待され る*2が，上の結果から見ればおそらく4であろうと推定される。 しかしこれだけでは明らかでない。

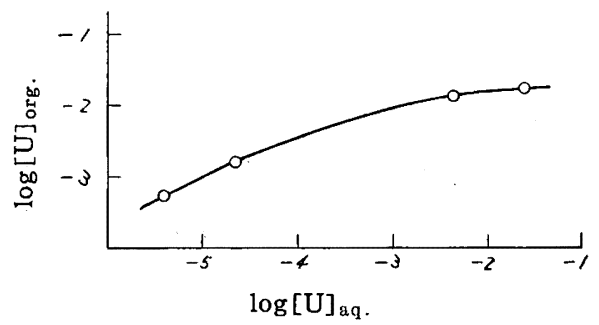

ベンジルド゙シルアミン: $0.1 \mathrm{~mol} / l, \mathrm{H}_{2} \mathrm{SO}_{4}: 0.1 \mathrm{~N}$

図 4 ウランの濃度変化による抽出平衡

いまウランにアミンの配位している数 $n$ 孛任意に 4, 5, 6 と し，これから結合に与からないで存在している遊剔のアミンの浱 度を求めると，抽出比との間にはつぎの実験式が得られる8)。

$$
D_{\mathrm{a}}^{0}(\mathrm{U})=k\left(C_{\Sigma_{\text {amine }}}-n C_{\text {Uorg. }}\right)
$$

ここで $C_{\Sigma_{\text {amine }}}$ は最初とったア乏ンの浱度, $C_{\text {Uorg. }}$ は有機層 に抽出されたウランの浱度である。

この関係を図 5 にあげた。図で $n=4$ のときは直線が得られる

7) R. H. Betts, R. K. Michels,J. Chem. Soc. Supp. Issue 286, 5289 (1949).

*2 ウランの配位数は 8 とされており， $1: 1$ の确酸錯塩は $\mathrm{UO}_{2} \mathrm{SO}_{4}\left(\mathrm{OH}_{2}\right)_{5}$ であろう. ウランに配位している 2 個の水分子は他の分子あるいはイオンで

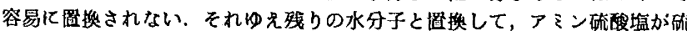
酸根を通して (3) のように配位するならば㻓大6储しか配位できない，C K. Jørgensen, Acta Chem. Scand. 8, 1503 (1954) 参㸟.

8) W J. McDowell, C. F. Baes, J. Phys. Chem. 62, 777 (1958); C. F. Coleman, K. B. Brown, J. G. Moore, D. J. Crouse, Ind. Eng. Chem. 50, 1756 (1958) など参照.
が, $n=5$ あるいは 6 の場合にはわん曲する。これからベンジル ドデシルアミンはウランに 4 個配位していることがわかり，アミ ン会合体の組成は $\left[\left(\mathrm{RR}^{\prime} \mathrm{NH}_{2}\right)_{2} \mathrm{SO}_{4}\right]_{2} \cdot \mathrm{UO}_{2} \mathrm{SO}_{4}$ であらわされる。 アミンが 6 個䦿位できないのはおそらくウランに配位したアそン 相互の反ぱつによるものと考えられる。

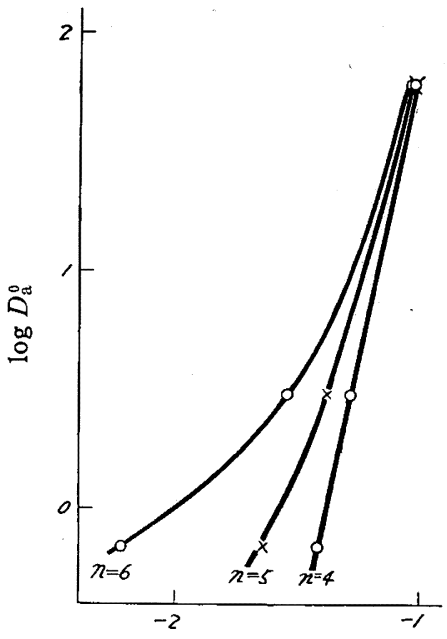

$\log \left\{\Sigma[\right.$ Amine $\left.]-n[U]_{\text {org. }}\right\}$

図 5 アミン会合体の組成決定

アミンの窒素原子は $p^{3}$ あるいは $s p^{3}$ 混成の共有結合かあるい は1洒のイオン的な結合のいずれかしかできないが*3, Carswell ら9) が指摘しているように，この場合前 2 者は考元難い。上の実 験結果からアミン硫酸塩が $1: 1$ の硫酸ウラニル分子に配位して, その配位している水分子と㗐換したものと考えられる。したがっ

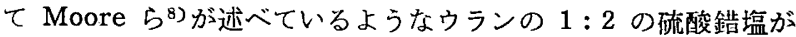
イオン交換的にアミンと静電結合をすることは考え難い。この問 題については今後実験を進めて明らかにしたいと考えている。

終りにのぞみ終始御琶篤な御指導觉賜わった東北大学岡 好良 教授に心から御礼申し上げる。またベンジルドデルアミンの試 藥を御恵与下され種々貴重な御览惨を睗わった東北大学選鉱製鍊 研究所山崎太郎教授に，また実験を御援助下さった阿部美保子理 学士に樑謝する。

(1959 年 4 月, 日本化学会第 12 年会講演)

*3 $N$ の場合は $s p^{3} d$ の trigonal な bipyramidal の炌道を使う可能性仗 はとんどない.

9) D. J. Carswell, J. J. Lawrance, J. Inorg. Nucl. Chem. 11, 69 (1959).

\section{ベルベリンの陽イオン交換樹脂に対する挙動}

（昭和 35 年 7 月 22 日受理）

$$
\text { 渡辺兵蔵† }
$$

ベルベリンの陽イオン交換についての基磱实驗を行なった。強酸性扰よび弱酸性のイオン交換樹脂を用いて，ベルベリンの交換 财着性と溶晟性をバッチ法とカラム法で比較した。

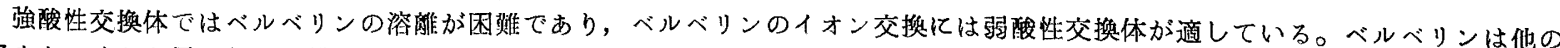
アルカロイドと巽なり, 遊離塩基の形でも $\mathrm{Na}$ ·形, $\mathrm{NH}_{4}$ 形などのイオン交換樹脂によく吸着される。またH形の場合は溶晟液の

\footnotetext{
$\dagger$ 山形工業高等学柲, 山形市緑町
} 